\title{
Analisis Daya Dukung Lahan Pertanian untuk Menjamin Keamanan Pangan di Kepulauan Kei Besar Kabupaten Maluku Tenggara
}

\author{
Pieter J. Kunu \\ Fakultas Pertanian Universitas Pattimura \\ Jl. Ir. M. Putuhena Kampus Poka Ambon, 97233 \\ Email : pieterkunu@gmail.com
}

\begin{abstract}
Abstrak
Penelitian untuk menguji daya dukung pangan khususnya beras untuk menjamin keamanan pangan di Kepulauan Kei Besar Kabupaten Maluku Tenggara, telah dilakukan. Hasil penelitian menunjukkan bahwa kecamatan yang tergolong wilayah yang telah mampu berswasembada pangan dan mampu memberikan kehidupan yang layak bagi penduduknya yaitu Kecamatan Kei Besar, Kei Besar Utara Barat dan Kei Besar Selatan Barat. Sementara Kecamatan Kei Besar Selatan termasuk wilayah yang mampu swasembada pangan tetapi belum mampu memberikan kehidupan yang layak bagi penduduknya. Sebaliknya Kecamatan Kei Besar Utara Timur tergolong wilayah yang belum mampu berswasembada pangan, hal ini disebabkan karena jumlah penduduk optimal yang sesuai dengan ketersediaan pangan beras adalah hampir 2000 penduduk lebih sedikit dari total jumlah penduduk eksisting. Hal ini menunjukkan bahwa jumlah penduduk dan kebutuhan pangan beras di Kecamatan Kei Besar Utara Timur tidak seimbang dengan ketersediaan pangan beras yang dihasilkan sepanjang tahun, artinya terjadi ancaman keamanan pangan di wilayah ini. Untuk itu, mengingat wilayah kecamatan lain memiliki jumlah penduduk yang masih jauh dari batas optimalnya, maka beberapa kebijakan yang dapat direkomendasikan adalah: (1) perluasan lahan pertanian padi ladang pada lahan yang sesuai, (2) migrasi penduduk ke kecamatan yang masih jarang penduduknya; (3) sharing produk pangan beras dari wilayah yang surplus ke wilayah yang deficit dan atau (4) pemerataan pembangunan untuk memecah konsentrasi penduduk di wilayah ini.
\end{abstract}

Kata Kunci: Daya dukung lahan, Keamanan pangan, Kepulauan Kei, Jumlah optimal penduduk

\section{Analysis of Carrying Capacity of Agricultural Land to Ensure Food Security in the Kei Besar Islands, Southeast Maluku Regency}

\begin{abstract}
Study on assessment carrying capacity of food, especially rice to ensure food security was conducted in the Kei Besar Islands, Southeast Maluku Regency. The results showed that district of Kei Besar has ability to food self-sufficient and to provide a proper life for its community in Northwest and Southwest Kei Besar. While, district of South Kei Besar is able to be self-sufficiency in food but has not able to provide a better life for its communities. On the other hand, district of Northeast Kei Besar is classified as an incapable area to food self-sufficient because the existing population is greater than the availability of rice to food self-sufficiently, namely 2000 people. This shows that there is no balance between the population, demand and the availability of rice in district of Northeast Kei Besar during the year. This means that this area is threatened with food insecurity. By considering the population in this district which is still high above the optimal food self-sufficiently, the following policies are recommended: (1) expansion of upland rice farming on suitable land, (2) migration of population to other less-populated districts; (3) sharing of rice food products from surplus areas to deficit areas and or (4) equitable development to divide population concentrations in these areas.
\end{abstract}

Keyword: Land carrying capacity, Food security, Kei Islands, Optimal population 


\section{PENDAHULUAN}

Bertambahnya jumlah penduduk serta aktivitas pembangunan yang terus berlangsung telah berdampak pada makin berkurangnya luas lahan pertanian produktif oleh sebab adanya alih fungsi lahan untuk berbagai kebutuhan. Hal ini telah menimbulkan dampak selanjutnya berupa menurunnya produksi pangan sehingga ketersediaan pangan semakin rendah dan tidak seimbang dengan permintaan atau kebutuhan penduduk. Berdasarkan kondisi ini, maka pemerintah melalui peraturan perundangan mewajibkan setiap bentuk perencanaan pembangunan di daerah maupun secara nasional wajib menyusun perencanaan pembangunan berwawasan lingkungan untuk menjamin bahwa pelaksanaan pembangunan telah mengintegrasikan konsepsi pembangunan berkelanjutan. Salah satu instrumen penjaminan perencanaan pembangunan telah berwawasan lingkungan adalah Kajian Lingkungan Hidup Strategis (KLHS) ${ }^{[1]}$.

Berdasarkan UU 32/2009 Pasal 16, Kajian Lingkungan Hidup Strategis (KLHS) harus memuat kajian antara lain terhadap kapasitas daya dukung dan daya tampung lingkungan hidup untuk menjamin terlaksananya pembangunan berkelanjutan. Pengertian Daya Dukung dan Daya Tampung seperti yang tercantum dalam regulasi ini adalah (1) kemampuan lingkungan hidup untuk mendukung perikehidupan manusia, mahluk lain, dan keseimbangan antar keduannya sebagai Daya Dukung lingkungan hidup dan (2) kemampuan lingkungan hidup untuk menyerap zat, jazad renik, dan/atau komponen lain yang masuk atau dimasukkan ke dalamnya sebagai Daya Tampung lingkungan hidup ${ }^{[2]}$.

Dalam penyelenggaraan pembangunan ekonomi nasional maupun daerah senantiasa berdampak pada ketidakseimbangan ekosistem sebab terjadi degradasi lingkungan hidup dan sumberdaya alam baik hutan, tanah, air, maupun udara. Keseluruhan dampak ini bermuara pada kesejahteraan hidup manusia yang ikut terganggu bahkan terancam kelangsungan hidupnya. Sehubungan dengan adanya problematika lingkungan hidup yang telah menjadi isu nasional bahkan global, lahirlah gerakan penyelamatan lingkungan hidup yang menghasilkan berbagai kebijakan internasional dan selanjutnya diadopsi oleh berbagai negara termasuk Indonesia dengan berbagai perangkat regulasi tentang perlunya penyelenggaraan pembangunan secara berkelanjutan yang tentunya berwawasan lingkungan hidup. Konsep ini dalam implementasinya bertumpu pada batas-batas daya dukung dan daya tampung lingkungan hidup suatu wilayah. Untuk maksud ini, maka untuk penyelanggaran pembangunan harus didahului dengan dilakukannya KLHS ${ }^{[3]}$.

Sesuai Undang-Undang 32 Tahun 2009, Pemerintah dan Pemerintah Daerah diwajibkan untuk menyusun KLHS untuk memastikan bahwa prinsip-prinsip pembangunan berkelanjutan telah menjadi dasar bahkan terintegrasi dalam pembangunan suatu wilayah, baik dalam kebijakan, rencana dan program (KRP) pembangunan serta dimasukkan dalam penyusunan dan/atau evaluasi RTRW, RPJP, RPJM Nasional dan juga RPJM Daerah. Salah satu muatan yang wajib ada dalam KLHS adalah daya dukung dan daya tampung lingkungan hidup (DDDTLH). Apabila DDDTLH telah terlampaui maka KRP pembangunan tersebut harus diperbaiki sesuai hasil KLHS, dan segala usaha yang telah melampaui DDDT lingkungan hidup, tidak diperbolehkan lagi. Mengacu pada regulasi tersebut, maka analisis DDDTLH lingkungan hidup menjadi sangat penting dan sangat dibutuhkan dalam pembangunan berkelanjutan dan harus disusun pada setiap jenjang pemerintahan seperti yang telah dilaksanakan oleh Pemerintahan Kabupaten Maluku Tenggara.

Kabupaten Maluku Tenggara merupakan satu dari 12 gugus pulau di Maluku. Kabupaten ini terdiri atas beberapa wilayah kepulauan, dan sampai saat ini 
setidaknya dua wilayah kepulauan yaitu Kepulauan Kei Kecil dan Kepulauan Kei Besar. Kepulauan Kei Besar terus bertumbuh; dan karenanya analisis mengenai daya dukung pertanian menjadi sangatlah penting mengingat jumlah penduduk yang terus meningkat sehingga mendorong permintaan pangan yang meningkat pula. Daya dukung wilayah untuk lahan pertanian merupakan kemampuan suatu wilayah guna memenuhi kebutuhan pangan penduduk setempat untuk dapat hidup sejahtera. Untuk itu perlu dilakukan penelitian untuk memperoleh gambaran daya dukung pangan khususnya komoditi padi ladang di Kabupaten Maluku Tenggara khususnya di Kepulauan Kei Besar.

Penelitian ini bertujuan untuk : (1) menentukan sebaran spasial berbasis kecamatan daya dukung lahan pertanian di Wilayah Kepulauan Kei Besar, (2) menghitung jumlah penduduk optimal yang mampu dipenuhi pangan oleh lahan padi ladang (3) menguji keamanan pangan dan (4) menetapkan alternatif rekomendasi pengelolaan lahan, pembangunan dan penduduk di wilayah Kepulauan Kei Besar.

\section{BAHAN DAN METODE}

\section{Lokasi dan Waktu}

Penelitian ini dilaksanakan di Kepualaun Kei Besar yang terdiri atas beberapa kecamatan di wilayah Administrasi Kabupaten Maluku Tenggara. Penelitian telah dilaksanakan pada bulan Agustus hingga November 2019.

\section{Pendekatan Yang digunakan}

Analisis daya dukung lahan pertanian untuk penyediaan pangan dilakukan dengan pendekatan ketersediaan-kebutuhan yang merupakan indikator yang sederhana, namun dapat digunakan untuk menunjukkan apakah suatu wilayah dapat swasembada ataukah tidak - diukur dari ketersediaan bahan pangan khususnya beras. Dalam daya dukung lahan pertanian di antaranya mengacu pada konsep produktivitas lahan pertanian dalam mencukupi atau mendukung kebutuhan fisik minimum setiap penduduk artinya daya dukung baik jika produksi lahan mampu mencukupi kebutuhan khususnya pangan bagi penduduknya. Parameter yang digunakan untuk mengukur tingkat daya dukung lahan pertanian terbatas pada empat indikator, yakni: luas lahan panen (ha), jumlah penduduk (jiwa), Kebutuhan Fisik Minimum (kg/kapita/tahun) dan produksi lahan rata-rata per hektar $(\mathrm{kg} / \mathrm{ha})$ $[2,4]$.

Pendekatan yang mengartikan daya dukung sebagai tingkat swasembada pangan wilayah; wilayah dipandang sebagai ekosistem pertanian. Kebutuhan Fisik Minimum (KFM) yang diperlukan untuk menentukan besarnya daya dukung wilayah lahan pertanian, sangat dipengaruhi oleh jumlah penduduk dan kondisi wilayahnya. KFM penduduk kota yakni sebesar $480 \mathrm{~kg} / \mathrm{kapita} / \mathrm{tahun}$, dan KFM penduduk desa yakni $320 \mathrm{~kg} / \mathrm{kapita} / \mathrm{tahun}$ (yang lain memberikan $265 \mathrm{~kg} / \mathrm{kapita} / \mathrm{tahun}$ ). Kebutuhan Fisik Minimum penduduk desa yang digunakan di sini yaitu KFM $=320$ $\mathrm{kg} / \mathrm{kapita} / \mathrm{tahun}$ sesuai dengan kondisi wilayahnya ${ }^{[5]}$.

Produksi per satuan luas dan waktu, dipergunakan rata-rata produksi padi per hektar per tahun. Hasil per satuan luas ditentukan oleh iklim dan tingkat kesuburan tanah, semakin tinggi curah hujannya maka makin tinggi pula hasil produksi yang di dapat dan mengakibatkan daya dukungnya makin tinggi, hal ini berlaku sebaliknya. Tingkat kesuburan tanah sangat berpengaruh terhadap produksi pertanian ${ }^{[6]}$.

\section{Metode Penelitian}

Penelitian menggunakan metode survey dengan teknik wawancara dan pengumpulan data sekunder yang diperoleh dari Badan Pusat Statistik dan intansi/lembaga yang terkait dengan penelitian ini.

\section{Konsep Pengukuran Variabel}


1. Luas Panen tanaman pangan adalah jumlah luas lahan yang ditanami tanaman pangan dalam satu tahun, dalam hektar (ha).

2. Produksi tanaman pangan di masingmasing wilayah kecamatan $(\mathrm{kg})$.

3. Luas lahan per kapita yang diperlukan untuk swasembada pangan (ha).

4. Jumlah kalori tanaman pangan adalah jumlah kandungan kalori setara kilogram beras masing-masing tanaman pangan. Dimana 1 Kilogram beras sebesar 3.610 kalori, 1 kilogram Jagung sebesar 3.600, 1 kilogram ubi kayu sebesar 1.460 kalori, 1 kilogram ubi jalar sebesar 1.230 kalori, 1 kilogram kacang tanah sebesar 4.520 kalori dan 1 kilogram kedelai 3.310 kalori.

5. Jumlah penduduk (jiwa).

\section{Metode Analisis Data}

Penelitian ini mengunakan analisis data yang menentukan tingkat daya dukung lahan pertanian tanaman pangan digunakan rumus dari konsep gabungan atas teori Odum, Christeiler, Ebenezer Howard ${ }^{[6,7]}$ yaitu : $\odot=$ $\frac{\mathrm{X}}{\mathrm{K}}$, ketengan : $=$ Tingkat daya dukung lahan pertanian, $X=$ Luas panen tanaman pangan per kapita, dan $\mathrm{K}=$ Luas lahan untuk swasembada pangan, dengan :
$\mathrm{X}=\frac{\text { Luas Panen (ha) }}{\text { Jumlah Penduduk (Jiwa) }}$

$\mathrm{K}=\frac{\text { Kebutuhan Fisik Minimum (KFM) }}{\text { Produksi tanaman pangan (ha/thn) }}$

$\mathrm{K}=\frac{\text { Luas Panen } \times \text { Produksi/hektar/thn) }}{\text { Jumlah penduduk } \times \text { KFM }}$

Di sini, KFM setara dengan 2600 Kalori per kapita per hari atau 265 kilogram beras per orang per tahun ${ }^{[8]}$.

\section{HASIL DAN PEMBAHASAN}

\section{Keadaan Umum Lokasi Penelitian}

Kepulauan Kei Besar merupakan bagian dari wilayah Kabupaten Maluku Tenggara. Luas kepulauan ini mencapai $550,05 \mathrm{~km}^{2}$. Kondisi lahan secara umum didominasi oleh lahan berbukit dan bergunung dengan ketinggian lebih dari 100 mdpl. Di perairan Kepulauan Kei Besar ditemukan beberapa jenis lamun yang cukup berlimpah. Masyarakat di wilayah ini juga memanfaatkan vegetasi mangrove sebagai bahan bangunan sehingga luasan kawasan ini semakin sempit (Gambar 1). 


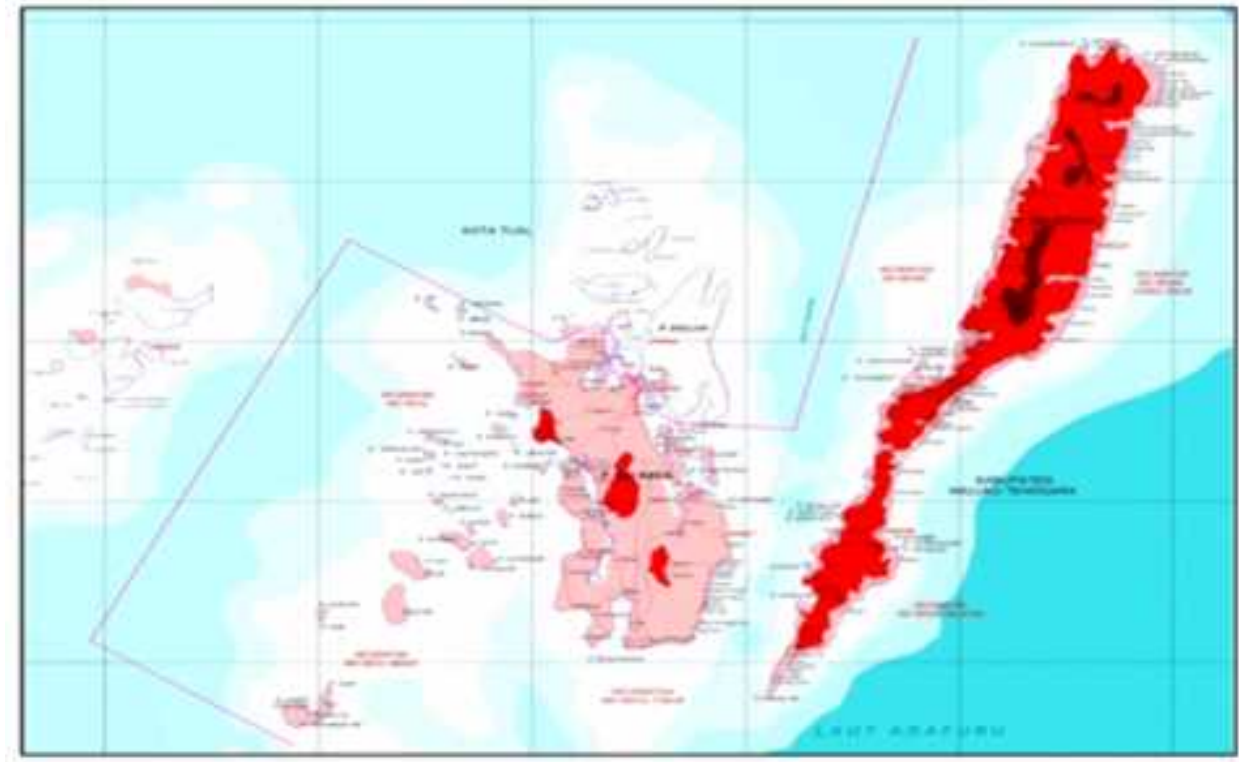

Sumber: RTRW Maluku Tenggara 2012-2032

Keterangan:

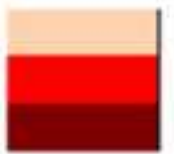

Ketinggian Lahan $0-100 \mathrm{mdpl}$

Ketinggian Lahan $100-500$ mdpl

Ketinggian Lahan $>500$ mdpl

Gambar 1. Kondisi Lahan di Kepulauan Kei Besar dan Kei Kecil

Iklim di wilayah ini dipengaruhi oleh Laut Banda, Laut Arafura dan Samudera Indonesia juga dibayangi oleh Pulau Papua di bagian timur dan Benua Australia di bagian selatan, sehingga sewaktu-waktu terjadi perubahan. Keadaan musim teratur, musim timur berlangsung dari Bulan April sampai Oktober. Musim ini adalah musim kemarau. Musim barat berlangsung dari Bulan Oktober sampai Februari. Musim hujan pada Bulan Desember sampai Februari dan yang paling banyak pada Bulan Desember dan Februari. Bulan Oktober sampai Maret bertiup angin Barat Laut sebanyak 50\% dengan angin Barat Laut dominan 28\%. Musim Pancaroba berlangsung dalam Bulan Maret/April dan Bulan Oktober/November. Bulan April sampai Oktober, bertiup angin Timur Tenggara. Angin kencang bertiup pada Bulan Januari dan
Februari diikuti dengan hujan deras dan laut bergelora. Bulan April sampai September bertiup angin Timur Tenggara dan Selatan sebanyak $91 \%$ dengan angin Tenggara dominan 61\%. Bulan Oktober sampai Maret bertiup angin Barat Laut sebanyak 50\% dengan angin Barat Laut dominan 28\% ${ }^{[9,10]}$.

Sungai yang berair sepanjang tahun di Kepulauan Kei Besar tercatat sebanyak sembilan aliran sungai dari total 13 aliran sungai Kabupaten Maluku Tenggara.

\section{Daya Dukung Lahan Pertanian}

Hasil analisis daya dukung lahan pertanian (dengan komoditi padi) dan jumlah penduduk optimal di Kepulauan Kei Besar disajikan dalam Tabel 1 
Tabel 1. Daya dukung lahan pertanian (padi) di Kepulanan Kei Besar Kabupaten Malukn Tenggara

\begin{tabular}{clcccccc} 
N & Kecamatan & $\begin{array}{c}\text { Jumlah } \\
\text { Penduduk } \\
\text { (Jiwa) }\end{array}$ & $\begin{array}{c}\text { Luas } \\
\text { Areal } \\
\text { (la) }\end{array}$ & $\begin{array}{c}\text { Luas } \\
\text { Panen } \\
\text { (ha) }\end{array}$ & $\begin{array}{c}\text { Produksi } \\
\text { (ton) }\end{array}$ & $\begin{array}{c}\text { Daya } \\
\text { Dukung } \\
\text { Tahan }\end{array}$ & $\begin{array}{c}\text { Kclas } \\
\text { Daya } \\
\text { Duknng }\end{array}$ \\
\hline 1 & Kei Besar & 15.633 & 88 & 73 & 211.7 & 3.730 & Tinggi \\
2 & Kei Besar Utara Timur & 9.890 & 69 & 27 & 78.3 & $\mathbf{0 . 8 0 7}$ & Rendah \\
3 & Kei Besar Selatan & 5.359 & 47 & 29 & 84.1 & 1.717 & Sedang \\
4 & Kei Besar Utara Barat & 7.473 & 80 & 61 & 176.9 & 5.449 & Tinggi \\
5 & Kei Besar Selatan Barat & 2.438 & 48 & 26 & 75.4 & 3.034 & Tinggi \\
\hline & Jumlah & 40.793 & 332 & 216 & 26 & 2.79 & Tinggi
\end{tabular}

Sumber: BPS 14.111

Keleraigan

Kəlas $1: \sigma \times 2,1$ ? Wilayah yang manpu swasembada pangan dan mampu memberikan kehidupan yisig layeak bag1 pendudukilys.

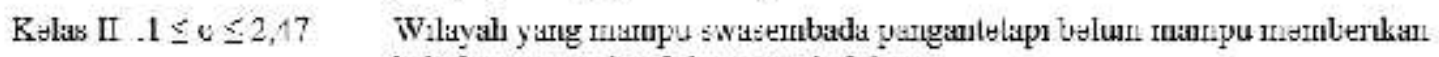

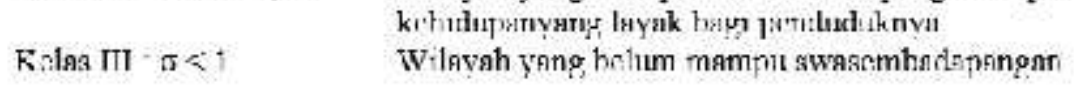

Berdasarkan pada data Tabel 1 maka ditemukan bahwa kecamatan yang memiliki kemampuan daya dukung yang tinggi adalah kecamatan Kei Besar, Kei Besar Utara Barat, Kei Besar Selatan Barat. Kemampuan daya dukung yang tinggi ini disebabkan terutama karena jumlah penduduk yang tersebar di kecamatan-kecamatan ini berada di bawah jumlah penduduk optimal. Hal ini menunjukkan bahwa jumlah ketersediaan pangan beras lebih besar terhadap jumlah kebutuhan penduduk setempat.

Jumlah penduduk di Kecamatan Kei Besar, Kei Besar Utara Barat, Kei Besar Selatan Barat mengacu pada kebutuhan penduduk akan pangan dibandingkan dengan ketersediaan pangan beras maka, jumlah penduduk masih dapat ditingkatkan hingga mencapai $54 \%$ sampai $373 \%$ dari jumlah penduduk saat ini, dengan ketentuan semua komponen lain yang terkait berada pada kondisi yang tetap.

Hasil analisis sebagaimana disajikan dalam Tabel 1 juga menunjukkan bahwa kondisi existing di Kepulauan Kei Besar Kabupaten Maluku Tenggara memiliki daya dukung penyediaan pangan yang baik yang diindikasikan dengan surplus pangan beras kecuali di Kecamatan Kei Besar Utara Timur. Kondisi ini dimungkinkan oleh adanya jumlah penduduk yang cukup besar sebagaimana data di atas. Jumlah penduduk yang besar ini tentu membutuhkan pangan beras yang lebih banyak, namun dengan keterbatasan lahan pertanian dan atau produktivitas yang rendah maka kebutuhan akan pangan beras yang ada tidak mampu dipenuhi; dengan kata lain daya dukung pangan beras tidak seimbang dengan permintaan penduduk dalam hal kebutuhan pangan beras.

Hubungan daya dukung dan kemampuan swasembada dan kesejahteraan penduduk di wilayah tersebut disajikan pada Tabel 2. Berdasarkan data tersebut, semua kecamatan yang memiliki kemampuan daya dukung yang tinggi yakni Kei Besar, Kei Besar Utara Barat, Kei Besar Selatan Barat, sekaligus menunjukkan bahwa kecamatankecamatan ini memiliki kemampuan untuk swasembada pangan dan mampu memberikan kehidupan yang layak bagi penduduknya. Sementara Kecamatan Kei Besar Selatan juga sudah memiliki kemampuan swasembada pangan tetapi belum mampu memberikan kehidupan yang layak bagi penduduknya. Sebaliknya wilayah Kecamatan Kei Besar 
Utara Timur yang memiliki daya dukung lahan pertanian yang rendah sudah tentu menunjukkan ketidakmampuannya untuk swasembada pangan (beras).

Tabel 2. Rangkuman Hasil Analisis Daya Dukung Lahan Pertanian Kabupaten Maluku Tenggara

\begin{tabular}{|c|c|c|c|c|}
\hline Kelas & $\begin{array}{l}\text { Daya Dukung } \\
\text { Lahan } \\
\text { Pertanian }\end{array}$ & $\begin{array}{c}\text { Kelas } \\
\text { Daya } \\
\text { Dukung }\end{array}$ & Kecamatan & Keterangan \\
\hline I & $\sigma>2,47$ & Tinggi & $\begin{array}{l}\text { Kei Besar, Kei } \\
\text { Besar Utara Barat, } \\
\text { Kei Besar Selatan } \\
\text { Barat }\end{array}$ & $\begin{array}{l}\text { Mampu swasembada pangan } \\
\text { dan mampu memberikan } \\
\text { kehidupan yang layak bagi } \\
\text { penduduknya. }\end{array}$ \\
\hline II & $1<\sigma<2,47$ & Sedang & Kei Besar Selatan & $\begin{array}{l}\text { Mampu swasembada pangan } \\
\text { tetapi belum mampu } \\
\text { memberikan kehidupan yang } \\
\text { layak bagi penduduknya }\end{array}$ \\
\hline III & $\sigma<1$ & Rendah & $\begin{array}{l}\text { Kei Besar Utara } \\
\text { Timur }\end{array}$ & $\begin{array}{l}\text { Belum mampu swasembada } \\
\text { pangan }\end{array}$ \\
\hline
\end{tabular}

Sumber : Olahan hasil analisis (2020)

\section{Jumlah Penduduk Optimal}

Hasil analisis jumlah penduduk optimal yang menggambarkan jumlah penduduk maksimal di wilayah kecamatan yang dikaji yang mampu didukung oleh produksi pangan beras adalah seperti disajikan dalam Tabel 3.

Tabel 3. Daya dukung lahan pertanian (padi) dan jumlah penduduk optimal di Beberapa Kecamatan Kei Besar Kabupaten Maluku Tenggara

\begin{tabular}{|c|c|c|c|c|c|c|c|c|}
\hline No. & Kecamatan & $\begin{array}{c}\text { Jumlah } \\
\text { Penduduk } \\
\text { (Jiwa) }\end{array}$ & $\begin{array}{l}\text { Luas } \\
\text { Areal } \\
\text { (ha) }\end{array}$ & $\begin{array}{l}\text { Luas } \\
\text { Panen } \\
\text { (ha) }\end{array}$ & $\begin{array}{l}\text { Produksi } \\
\quad \text { (ton) }\end{array}$ & $\begin{array}{c}\text { Daya } \\
\text { Dukung } \\
\text { Lahan }\end{array}$ & $\begin{array}{c}\text { Kelas } \\
\text { Daya } \\
\text { Dukung }\end{array}$ & $\begin{array}{l}\text { Jumlah } \\
\text { Penduduk } \\
\text { Optimal }\end{array}$ \\
\hline 1 & Kei Besar & 15.633 & 88 & 73 & 211.7 & 3.730 & Tinggi & 58.317 \\
\hline 2 & Kei Besar & & & & & & & \\
\hline & $\begin{array}{l}\text { Utara } \\
\text { Timur }\end{array}$ & 9.890 & 69 & 27 & 78.3 & 0.807 & Rendah & 7.978 \\
\hline 3 & $\begin{array}{l}\text { Kei Besar } \\
\text { Selatan }\end{array}$ & 5.359 & 47 & 29 & 84.1 & 1.717 & Sedang & 9.203 \\
\hline 4 & $\begin{array}{l}\text { Kei Besar } \\
\text { Utara Barat }\end{array}$ & 7.473 & 80 & 61 & 176.9 & 5.449 & Tinggi & 40.720 \\
\hline 5 & $\begin{array}{l}\text { Kei Besar } \\
\text { Selatan } \\
\text { Barat }\end{array}$ & 2.438 & 48 & 26 & 75.4 & 3.034 & Tinggi & 7.398 \\
\hline & Jumlah & 40.793 & 332 & 216 & 26 & 2.79 & Tinggi & 86.968 \\
\hline
\end{tabular}


Kunu J.P, 2020. Daya Dukung Lahan ...

Secara keseluruhan maka jumlah penduduk optimal yang masih dapat didukung dengan kondisi pangan (beras) di saat ini dapat mencapai $213,0 \%$ dari jumlah penduduk yang ada saat ini. Tentu saja dengan ketentuan produktivitas padi ladang dapat tetap dipertahankan seperti saat ini; akan tetapi kendala pada kecamatan Kei Besar Utara Timur yang memiliki jumlah penduduk yang melampaui jumlah penduduk optimal harus dicarikan solusi, dengan cara antara lain meningkatkan produktivitas padi atau adanya penataan penduduk agar tidak melampaui batas optimal yang disyaratkan.

Tabel 4 menyajikan data yang menunjukkan bahwa secara umum pada saat ini terjadi surplus penyediaan pangan terhadap kebutuhan pangan beras penduduk rata-rata di wilayah ini.

Tabel 4. Kemampuan Swasembada Beras (Daya Dukung Pangan Beras)

\begin{tabular}{llccccc}
\hline No. & \multicolumn{1}{c}{$\begin{array}{c}\text { Kecamatan/ } \\
\text { Subdistrict }\end{array}$} & $\begin{array}{c}\text { Jumlah } \\
\text { Penduduk } \\
\text { (Jiwa) }\end{array}$ & $\begin{array}{c}\text { Luas } \\
\text { Areal (ha) }\end{array}$ & $\begin{array}{c}\text { Luas Panen } \\
\text { (ha) }\end{array}$ & $\begin{array}{c}\text { Produksi } \\
\text { (kg) }\end{array}$ & Keterangan \\
\hline 1 & Kei Besar & 15633 & 88 & 73 & 211700 & Surplus \\
2 & Kei Besar Utara Timur & 9890 & 69 & 27 & 78300 & Surplus \\
3 & Kei Besar Selatan & 5359 & 47 & 29 & 84100 & Surplus \\
5 & Kei Besar Utara Barat & 7473 & 80 & 61 & 176900 & Surplus \\
6 & Kei Besar Selatan & 2438 & 48 & 26 & 75400 & Surplus \\
\hline & Barat & 40793 & 332 & 216 & 626400 & Surplus \\
\hline
\end{tabular}

Berdasarkan hasil analisis data actual sebagaimana disajikan pada Tabel 4 di atas, menunjukkan bahwa pada saat ini produksi dan ketersediaan beras yang ada di seluruh kecamatan di Kepulauan Kei Besar dalam keadaan Surplus. Fluktuasi produktivitas padi ladang di wilayah ini, terutama yang terjadi di Kecamatan Kei Besar Utara Timur menunjukkan bahwa walaupun saat ini terjadi surplus produksi beras, namun daya dukung lahan pertanian dengan komoditi padi ladang telah menunjukkan bahwa wilayah ini tergolong wilayah dengan daya dukung lahan pertanian yang rendah sehingga seringkali terjadi defisit. 


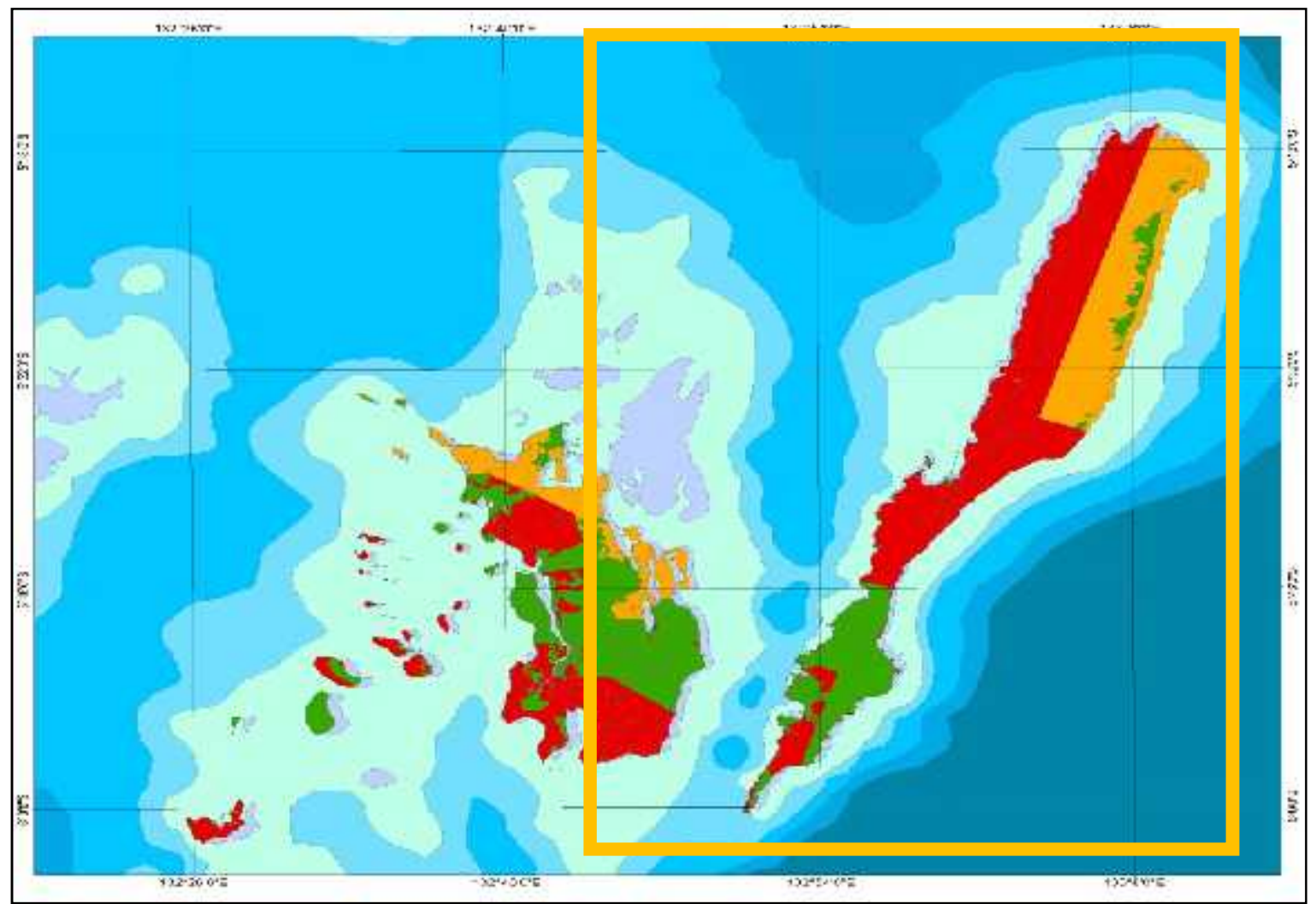

Sumber : Dokumen KLHS RPJMD Maluku Tenggara (2019)

Keterangan :

Indikasi Daya Dukung
Fensah
sosung
Tnag

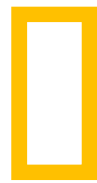

\section{Kepulauan Kei Besar}

Gambar 2. Peta Indikasi daya dukung penyediaan pangan

\section{KESIMPULAN}

1. Daya dukung lahan pertanian tanaman pangan di Kepulauan Kei Besar masih dapat diandalkan, kecuali Kecamatan Kei Besar Utara Timur yang masih rendah.

2. Jumlah penduduk optimal secara umum belum dicapai oleh seluruh kecamatan kecuali di Kecamatan Kei Besar Utara Timur yang sudah melampaui jumlah penduduk optimal.

3. Keamanan pangan di Kepulauan Kei Besar secara umum masih dapat diandalkan, hanya pada Kecamatan Kei
Besar Utara Timur yang masih harus dibenahi.

4. Beberapa kebijakan yang dapat direkomendasikan sebagai strategi penanganan daya dukung yang rendah adalah: (1) perluasan lahan pertanian padi ladang pada lahan yang sesuai, (2) migrasi penduduk ke kecamatan yang masih jarang penduduknya; (3) sharing produk pangan beras dari wilayah yang surplus ke wilayah yang deficit dan atau (4) pemerataan pembangunan untuk memecah konsentrasi penduduk di wilayah ini. 


\section{DAFTAR PUSTAKA}

[1] KLH, 2014. Pedoman Penentuan Daya Dukung Dan Daya Tampung Lingkungan Hidup. Deputi Bidang Tata Lingkungan Kementerian Lingkungan Hidup.

[2] Peraturan Pemerintah Republik Indonesia Nomor 46 Tahun 2016 Tentang Tata Cara Penyelenggaraan Kajian Lingkungan Hidup Strategis (KLHS)

[3] Permendagri No. 7 Tahun 2018 tantang Pembuatan dan Pelaksanaan KLHS dalam Penyusunan RPJMD

[4] Peraturan Menteri Negara Lingkungan Hidup Nomor 17 Tahun 2009 Tentang Pedoman Penentuan Daya Dukung Lingkungan Hidup Dalam Penataan Ruang Wilayah

[5] Nurlaila Mubarokah, Latief M. R., Suria D. Tarigan, 2020. Analisis Daya Dukung Lahan Pertanian Tanaman Pangan Daerah Aliran Sungai Cibaliung, Provinsi Banten (Analysis Cibaliung Watershed, Banten Province). Jurnal Ilmu Pertanian Indonesia (JIPI), Januari 2020 Vol. 25 (1): 73-80. ISSN 0853-4217
http://journal.ipb.ac.id/index.php/JIPI; EISSN 2443-3462

DOI:10.18343/jipi.25.1.73

[6] Moniaga dan R.B. Vicky. 2011. Analisis Daya Dukung Lahan Pertanian. ASE Volume 7 Nomor 2, Mei 2011: 61-68.

[7] Soehardjo dan Tukiran, 1990. Studi Literatur Konsep yang sudah ada Mengenai Daya Tampung Wilayah. Kantor Menteri Negara Kependudukan dan Lingkungan Hidup. Jakarta

[8] Celsius, Talumingan dan S.G. Jocom, 2017. Kajian daya dukung lahan pertanian dalam menunjang swasembada Pangan di Kabupaten Minahasa Selatan. Agri-SosioEkonomi

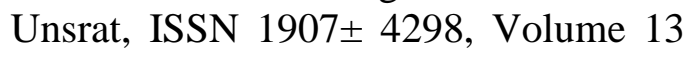
Nomor 1, Januari $2017: 23$ - 36

[9] BPS. 2018. Kabupaten Maluku Tenggara Dalam Angka. Badan Pusat Statistik Kabupaten Maluku Tenggara, Langgur.

[10] BPS. 2018. Provinsi Maluku Dalam Angka. Badan Pusat Statistik Provinsi Maluku, Ambon.

[11] BPS. 2017. Kabupaten Maluku Tenggara Dalam Angka. Badan Pusat Statistik Kabupaten Maluku Tenggara, Langgur. 